\title{
Preface: The practice and theory of automated timetabling (2018)
}

\author{
Ender Özcan ${ }^{1} \cdot$ Edmund K. Burke $^{2}$ - Luca Di Gaspero ${ }^{3}$. Barry McCollum ${ }^{4}$. \\ Nysret Musliu ${ }^{5}$
}

Accepted: 10 May 2021 / Published online: 26 May 2021

(C) The Author(s) 2021

Welcome to this special issue of the Annals of Operations Research. We are delighted to present you a selection of peer reviewed papers from the 12th International Conference on the Practice and Theory of Automated Timetabling (PATAT) that took place in Vienna, Austria, between the 28th and 31st of August, 2018. The PATAT conference series has been running biennially, apart from a three-year gap between 1997 and 2000. This special issue represents our sixth post-conference volume of papers in the Annals of Operations Research.

The PATAT series serves as a multi-disciplinary forum for all aspects of automated timetabling research. The 12th PATAT conference was held in TU Wien's Faculty of Informatics right in the center of Vienna. Eighty-five delegates from 21 different countries around the world joined the conference. The programme featured 54 presentations, including 4 plenary papers, 2 invited tutorials, 21 full papers and 27 extended abstracts. An itinerary of excellent plenary talks were given by Johannes Gärtner, Louis-Martin Rousseau, Hana Rudová and Pascal Van Hentenryck. We were also fortunate to have outstanding invited tutorials by Jeffrey Kingston and Andrea Schaerf.

We would like to express our gratitude to the Organising Committee, TU Wien and the wide range of dedicated individuals who made the 12th PATAT conference such a success, including Juliane Auerböck, Emir Demirović, Lucas Kletzander, Florian Mischek, Tommaso Urli and Felix Winter. Additionally, we thank the PATAT Programme Committee for their hard work in generating such rigorous and thorough reviews. We also owe a debt of thanks to the Steering Committee for their ongoing work in supporting the successful continuation of the series. Finally, we extend our gratitude to all the authors and delegates for their contributions to the conference.

Open Access This article is licensed under a Creative Commons Attribution 4.0 International License, which permits use, sharing, adaptation, distribution and reproduction in any medium or format, as long

Ender Özcan

ender.ozcan@nottingham.ac.uk

University of Nottingham, Nottingham, UK

University of Leicester, Leicester, UK

University of Udine, Udine, Italy

Queen's University, Belfast, UK

5 TU Wien (Technische Universität Wien), Vienna, Austria 
as you give appropriate credit to the original author(s) and the source, provide a link to the Creative Commons licence, and indicate if changes were made. The images or other third party material in this article are included in the article's Creative Commons licence, unless indicated otherwise in a credit line to the material. If material is not included in the article's Creative Commons licence and your intended use is not permitted by statutory regulation or exceeds the permitted use, you will need to obtain permission directly from the copyright holder. To view a copy of this licence, visit http://creativecommons.org/licenses/by/4.0/.

Publisher's Note Springer Nature remains neutral with regard to jurisdictional claims in published maps and institutional affiliations. 